https://doi.org/10.37208/tgn27407

\section{Donacaula forficella (Lepidoptera: Crambidae): a moth new to Scotland}

\author{
R.B. Weddle
}

89 Novar Drive, Glasgow G12 9SS

E-mail: richard@canto.plus.com

At Bowling Harbour, West Dunbartonshire on 3rd August 2018, Claire Martin of the Scottish Waterways Trust (now defunct) organised a Bioblitz. As part of the event, Alan Kerr ran moth traps the previous night in the Scottish Canals compound there, which attracted (in separate traps) single male and female specimens of Donacaula forficella. Their identification was confirmed by dissection of the genitalia by Mark Young, who added it as a new Scottish species to the unpublished List of Scottish Micro-moths which he maintains.

The moth was found again by Dean Stables beside the Glasgow branch of the canal at Ruchill, Glasgow on 1st July 2021, and was confirmed from the genitalia by Nigel Richards. Further specimens were found two days later by Alan Winthrop at an outside light in his garden, less than $100 \mathrm{~m}$ from the canal at Bishopbriggs, East Dunbartonshire (Fig. 1).

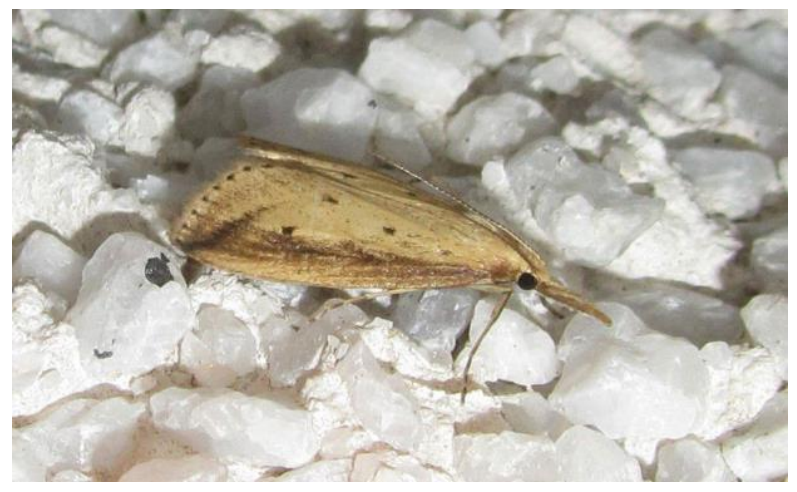

Fig. 1. Donacaula forficella female, forewing length $12 \mathrm{~mm}$, Bishopbriggs, East Dunbartonshire, Scotland, 3rd July 2021. (Photo: Alan Winthrop)

Donacaula forficella (Thunberg, 1794) has been given the English name pale water-veneer, reflecting its preferred wetland habitat, where the caterpillars feed on the leaves of plants such as reeds and sedges. It is described as local in those parts of Great Britain and Ireland where it has been recorded (Sterling et al., 2012). However, there were no previous records north of the southern parts of Lancashire and Yorkshire, England, though it has been recorded in Northern Ireland (NBN, 2021; Sterling et al., 2012). The fact that the first records were beside the Forth and Clyde Canal towards its western end, and the subsequent records were adjacent to the same canal in Glasgow and Bishopbriggs, suggests that the moth could be spreading eastwards along the canal. It may well be found in more easterly sections of the canal in future years.

It should be remembered that, on NBN distribution maps, the absence of occurrences in an area does not necessarily confirm absence of the species. On the other hand, the prior absence of the moth from the Young List of Scottish Micro-moths confirms that the moth had not been previously reported as occurring in Scotland.

The moth has not so far been recorded at the Scottish Canals compound at Applecross Basin, Hamiltonhill, further towards the city centre on the Glasgow branch of the canal, though it may well appear there once the canal vegetation has recovered from the recent development work in that section.

The 2018 sightings fell within the Watsonian vicecounty of Dunbartonshire (VC99) and the more recent records were in Lanarkshire (VC77).

I thank the recorders of the various sightings for sharing their information. Thanks also to Scottish Canals for allowing the use of their compound in Bowling, and to Alan Winthrop for the photograph shown in Fig. 1.

\section{REFERENCES}

National Biodiversity Network (NBN) Atlas (2021). https://species.nbnatlas.org/species/NHMSYS0000 502204 Accessed 1st November 2021.

Sterling, P., Parsons, M. \& Lewington, R. (2012). Field Guide to the Micro-moths of Great Britain and Ireland. British Wildlife Publishing, Dorset. 